\title{
Planning for Abundance: Permaculture and Radical Transformation
}

\author{
Jamie Vishwam Heckert ${ }^{1}$
}

While the most visible and vocal forms of radical politics emphasise conflict, protest and opposition, this paper champions some of the more quiet, cooperative and quotidian approaches to the challenges of our times. Focusing on the themes of food and justice, it takes inspiration from permaculture, an ethical design system inspired by nature. David Holmgren, one of the original founders of permaculture, suggests 12 design principles for use in creating sustainable systems. These principles are introduced and applied to a range of concerns relevance to the politics of food justice, from the practicalities of designing abundant gardens to the challenges of emotional sustainability during a period of great transformation. [Article copies available for a fee from The Transformative Studies Institute. E-mail address: journal@transformativestudies.org Website: http://www.transformativestudies.org (C2014 by The Transformative Studies Institute. All rights reserved.]

KEYWORDS: Permaculture, Abundance, Sustainability, Social Movements, Food Justice, Systems Thinking.

"When we try to pick out anything by itself we find that it is bound fast by a thousand invisible cords that cannot be broken, to everything in the universe. " - John Muir

The future, as always, is uncertain. As the dawning awareness spreads that fossil fuels are limited, that economic growth can only go so far, that our ecological systems are in peril, individuals and groups respond in different ways. For some, the answer is obviously to plan for scarcity.

\footnotetext{
${ }^{1}$ Jamie Vishwam Heckert holds a Ph.D. in Sociology from the University of Edinburgh, is a qualified Integral Yoga teacher and has completed the Permaculture Design Course. He is co-editor of Anarchism \& Sexuality: Ethics, Relationships and Power and of Queering Ecopsychology and contributor to numerous other publications on the themes of intimacy and transformation. Drawing on these experiences and more, he offers workshops, retreats and one-to-one support sessions for liberation. For more information, see http://heartoffreedom.org . Address correspondence to: Jamie Vishwam Heckert, Anarchist Studies Network; e-mail: Jamie.Heckert@gmail.com.
} 